\title{
Business R\&D and the Interplay of R\&D Subsidies and Product Market Uncertainty
}

\author{
Dirk Czarnitzki · Andrew A. Toole
}

Published online: 4 January 2008

(C) Springer Science+Business Media, LLC. 2007

\begin{abstract}
This paper examines the effect of product market uncertainty and government research and development $(R \& D)$ subsidies on firm-level R\&D investment. Using a sample of German manufacturing firms, we find that product market uncertainty reduces $R \& D$ investment and government $R \& D$ subsidies increase $R \& D$ investment. Moreover, our results indicate that $R \& D$ subsidies mitigate the effect of product market uncertainty on $R \& D$ investment. These findings suggest that public policies aimed at increasing business $R \& D$ investment can achieve this objective by reducing the degree of uncertainty in the product market.
\end{abstract}

Keywords R\&D Real options theory $\cdot$ Uncertainty

JEL Classification $\quad \mathrm{H} 25 \cdot \mathrm{L} 60 \cdot \mathrm{O} 3$

\section{Introduction}

Since business investment in research and development (R\&D) is a critical factor driving innovation and economic growth, it is important to understand how public

D. Czarnitzki $(\varangle)$

Department of Managerial Economics, Strategy and Innovation, K.U. Leuven, Naamsestraat 69, 3000 Leuven, Belgium

e-mail: dirk.czarnitzki@econ.kuleuven.be

D. Czarnitzki

ZEW, Mannheim, Germany

A. A. Toole

Department of Agriculture, Food and Resource Economics, Rutgers University, 55 Dudley Road, New Brunswick, NJ 08901, USA

e-mail: toole@aesop.rutgers.edu 
policies, such as R\&D subsidies, influence private incentives for R\&D investment. There is now a sizable literature on how public R\&D subsidies might "correct" for underinvestment in business $R \& D$ resulting from market failures or various capital market imperfections leading to financing constraints. ${ }^{1}$ Drawing on the theory of investment under uncertainty, this paper argues that public R\&D subsidies increase business R\&D investment through an additional mechanism - mitigating the effects of uncertainty on R\&D investment in markets for new products.

The real options approach to investment under uncertainty predicts that firms invest less in irreversible capital as uncertainty in expected future cash flows increases (Pindyck 1991; Dixit 1992; Dixit and Pindyck 1994). R\&D investment is highlighted in this literature as a particularly relevant example of irreversible capital since a large proportion of R\&D supports the salaries of research personnel and cannot be recouped if projects fail. In light of the fact that the output of $R \& D$ is inherently uncertain, firms can avoid large losses by waiting for new information about future market demand or competition and forgoing investment when this information is unfavorable. Hence, the incentive to invest in R\&D today is lower because it involves exercising or "killing" the option to invest productively at any time in the future.

The basic contribution of this paper is to show that public R\&D subsides can mitigate the incentive effect of product market uncertainty on firm-level R\&D investment and to test this possibility using firm-level data. Although public R\&D subsidies do not act directly to reduce product market uncertainties, they can offset the incentive effect of these uncertainties by increasing the expected return to the firm's R\&D investment. Our empirical results support this perspective on the interplay of R\&D subsidies and product market uncertainty. One implication from our analysis is that public policies intended to increase R\&D investment can achieve this objective by reducing the degree of uncertainty in the product market. Our findings support the use of demand-side incentive mechanisms such as purchase precommitments as suggested in a stream of research on spurring medical innovation and vaccine development by Kremer and Glennerster (2000) and Kremer (2001a,b).

The remainder of the paper is organized as follows: Section 2 briefly summarizes the necessary literature that is used to elaborate the main hypotheses that we test in this analysis. Section 3 introduces the data. The empirical results are presented in Section 4 , and the final section concludes.

\section{Literature and Hypotheses}

\subsection{Incomplete R\&D Appropriability and Financing Constraints}

The best known rationales for public R\&D subsides are incomplete R\&D appropriability and firm financing constraints. Nelson (1959) and Arrow (1962) argued that private incentives for investment in R\&D may lead to underinvestment because the

1 The seminal papers are Nelson (1959) and Arrow (1962). David et al. (2000) survey the empirical literature related to public R\&D subsidies. Hall (2002) surveys the literature on financing constraints due to capital market failures. 
knowledge generated through R\&D activities is non-excludable. Other economic actors may "capture" part of the value created from the original R\&D investment for use in their own innovative activities. When this happens, the social return is greater than the private return, and private firms under-invest in R\&D from a social perspective. Moreover, this incentive problem is even more acute for projects that involve more "basic" or "fundamental" research since valuable applications stemming from this type of investment are more difficult to foresee.

Public R\&D subsides are seen as one way to increase overall investment in R\&D in order to compensate for underinvestment due to incomplete appropriability. However, implementing this policy response is quite challenging and controversial. Ideally, public agencies would only grant subsidies for projects where the private return is insufficient to induce investment but the social return exceeds the R\&D cost of investment. Two main problems are identified: First, it is unclear whether the government can select those projects with high social returns but insufficient private returns. Second, once public support programs are in place, each firm has an incentive to apply for grants for any kind of $R \& D$ project because the marginal cost of a subsidy is zero (aside from its application cost). Thus firms might simply substitute public financing for private investment. This potential crowding out effect has been the subject of numerous empirical studies. David et al. (2000) and Klette et al. (2000) surveyed the literature and find that micro-econometric studies yield mixed results. For instance, David et al. report that nine out of nineteen studies find crowding-out effects. With the availability of better micro firm-level databases and new econometric methods, scholars tend to find that crowding out effects are rejected in more recent studies (see, for instance, Almus and Czarnitzki 2003; Duguet 2004; Czarnitzki and Licht 2006; González et al. 2006; Hussinger 2007; Toole 2007). Lach (2002) and Görg and Strobl (2007), however, still find mixed evidence. ${ }^{2}$

In addition to the incomplete appropriability argument, the literature on financial constraints points out that capital market imperfections also lead to private underinvestment in R\&D. A survey by Hall (2002) summarizes the findings as follows: Due to asymmetric information between borrowers and lenders a financing gap for R\&D emerges. Potential lenders such as banks are reluctant to fund $R \& D$ due to the inherent risk, even if the borrower has argued that there are high expected returns. Unlike investment in physical capital, $R \& D$ expenditure usually yields no tangible assets to use as collateral in credit negotiations. Thus R\&D must be supported predominantly by internal financial resources. This causes a financing gap for small and medium-sized firms that do not have sufficient cash-flow to fund R\&D. Surprisingly the financial constraints literature attempts to test for the existence of financial constraints but typically ignores the presence of R\&D subsidies. Two exceptions are Hyytinen and Toivanen (2005) and Czarnitzki (2006), who find that R\&D subsidies reduce the underinvestment problem stemming from financial constraints.

Hypothesis 1 Public R\&D subsidies increase R\&D investment by recipient firms.

\footnotetext{
2 A detailed discussion of these studies is beyond the scope of this paper. We refer the reader to a recent survey by Aerts et al. (2006).
} 


\subsection{Uncertainty and Investment}

In the theoretical literature, the direction of the effect of uncertainty on investment is ambiguous. One strand of research suggests that greater uncertainty will increase the investment of a risk-neutral competitive firm since the marginal value of capital is a convex function of the uncertain market price (Hartman 1972, Abel 1983). Another strand of the literature emphasizes the role of irreversibility of investment. When investment is irreversible, firms incur an additional opportunity cost by giving up the option to wait for more information. This line of research suggests that greater uncertainty will reduce the investment of a risk-neutral firm since the marginal value of capital is a concave function of the uncertain market price (McDonald and Siegel 1986; Bertola 1988; Pindyck 1988; Dixit and Pindyck 1994; Carruth et al. 2000).

Among the varieties of investment a firm might undertake, $R \& D$ investment is probably the most sensitive to uncertainty. $R \& D$ investment has a large human and tacit knowledge component making it one of the most irreversible types of capital investment. Thus, it is likely that R\&D investment is delayed and thereby reduced as uncertainties increase.

Our literature search found only one published empirical analysis on the relationship between uncertainty and R\&D investment. Using annual data for nine OECD countries over the period 1982-1992, Goel and Ram (2001) relate the share of R\&D and non$\mathrm{R} \& \mathrm{D}$ investment in GDP to indicators of aggregate inflation uncertainty, real interest rates, and the growth of GDP. The separate categories of R\&D investment and non$\mathrm{R} \& \mathrm{D}$ investment are intended to capture differences in the degree of irreversibility of the underlying investment decisions. They measure uncertainty using 5-year moving averages of each country's inflation rate in both standard deviation and level form. The results show that both versions of uncertainty reduce the share of R\&D in GDP but have no significant impact on the share of non-R\&D investment in GDP. Since irreversibility is one of the required characteristics for creating a positive option value for waiting, their results are consistent with real options investment behavior. ${ }^{3}$

Hypothesis 2 Greater uncertainty is associated with lower levels of firm R\&D investment since firms choose to hold back on exercising their investment options.

The main contribution of this paper is to point out that public R\&D subsidies can mitigate the incentive effect of uncertainty on firm-level R\&D investment. While these subsidies do not act directly to reduce uncertainties, they can offset the incentive to delay investment by increasing the expected return to the firm's R\&D investment. Therefore, uncertainty should affect the $R \& D$ investment of firms that receive public subsidies less than the R\&D investment of firms that do not receive public subsidies.

Hypothesis 3 Public R\&D subsidies mitigate the incentive effect of uncertainty for recipient firms.

\footnotetext{
3 While there appear to be no further empirical studies of the relationship between R\&D investment and uncertainty at the firm level, several researchers have investigated the broader relationship between firm investment (mostly physical assets) and various measures of uncertainty. Examples are Bulan (2005), Leahy and Whited (1996), Gusio and Parigi (1999) and Von Kalckreuth (2000).
} 


\section{Data}

The data source for our empirical analysis is the Mannheim Innovation Panel (MIP) which is an annual German innovation survey conducted by the Centre for European Economic Research (ZEW). It represents the German part of the Community Innovation Survey which is part of the harmonized innovation survey conducted by EU member states. It covers both public and private firms of all sizes in Germany.

Our sample is a pooled cross-section of 925 "innovative" firms taken from the 1999 and 2001 surveys for the manufacturing sector (the actual data correspond to the years 1998 and 2000). Although we have two years, we cannot make use of panel econometrics since most firms are only observed once: The 925 observations correspond to 702 different firms. Only $32 \%$ of firms are observed in both years. ${ }^{4}$ To identify innovative firms and to make use of pre-sample information on firm behavior, we supplement these data with pre-sample information obtained from earlier surveys. In our sample, an innovative firm is defined to be a company that introduced at least one new product into a market during the previous five or six years, 1992-1997 and 1995-1999, respectively.

The main dependent variable is $\mathrm{R} \& \mathrm{D}$ expenditure at the firm level $\left(R \& D_{i}\right)$ in millions of DM (1.95583 DM = 1 EUR). Although we consider only previous product innovators, we find that about $30 \%$ of the firms in the sample did not conduct R\&D in 1998 or 2000. This fact may itself reflect a reaction to high levels of uncertainty. Our econometric analysis takes this into account by modeling the censored distribution of R\&D. Above zero, the distribution of R\&D spending is quite skewed, and this motivates our logarithmic specification $\left(\ln R \& D_{i}\right)$. Since we cannot take the $\log$ of the censored observations at $R \& D_{i}=0$, we set those observations to the minimum observed positive $R \& D$ value in the sample and interpret this observed minimum as the censoring point in the regression models. As a robustness check, we also present the empirical results using R\&D intensity, $\ln \left(R \& D_{i} /\right.$ Sales $\left._{i}\right)$.

To test the hypotheses regarding uncertainty, we use a firm-specific proxy of expected product market uncertainty. We would like our proxy to capture aspects of uncertainty related to how the firm's products will perform when introduced into the marketplace. We selected revenue from sales as a good indicator of market performance because variation in sales revenue should reflect both consumer demand and competitive pressures in the marketplace. Given available data, we assume that firms form expectations about uncertainty regarding product market performance based on their past experience. Each firm's past experience is a combination of their experience with new product introductions as well as their experience with established products in the market. Performance in both these product categories will inform the firm's perception of uncertainty.

Product market uncertainty (UNCER) is measured as the variance of the share of sales (in \%) achieved with new products per year in the pre-sample period from 1992 to 1997 (for observations of $R \& D$ in 1998) and 1995 to 1999 (for $R \& D$ in 2000)

\footnotetext{
4 The survey questionnaire changes over time as it addresses topics of interest in current innovation policy. The panel structure can only be used for certain core questions on innovation indicators that are surveyed annually.
} 
at the firm level. Of course, this measure may be sensitive to time trends, or more specifically, to the typical diffusion patterns and product life-cycle characteristics of particular industries. For instance, new product diffusion is expected to be more rapid in the electronics industry than the steel industry due to differences in consumer and/or producer behavior within those industries. To adjust for this, the share of sales with new products of firm $i$ is normalized by the industry average..$^{5}$ The number of pre-sample observations available for each firm varies from three to six years:

$$
U_{N C E R_{i}}=\frac{1}{T} \sum_{t=1}^{T}\left(S_{i t}-\overline{S_{i}}\right)^{2}, \quad \text { where } S_{i t}=\frac{\text { Sales }_{i t}^{*}}{\overline{\text { Sales }_{j t}^{*}}}
$$

where Sales ${ }_{i t}^{*}$ denotes the share of sales achieved with new products in firm $i$ in year $t$, and Sales ${ }_{j t}^{*}$ refers to the industry's sales achieved with new products at NACE 3digit industry level. The variable UNCER captures the volatility of revenue from new market introductions. This measure will indicate greater levels of uncertainty as the performance of new products differs from that of established products relative to the firm's own industry average. Consistent with the real options theory, higher expected product market uncertainty should delay $R \& D$ investment and thereby have a negative impact on the level of R\&D investment.

To help identify real options investment behavior, we would like to have a reasonable control variable for a firm's risk preferences. We expect each firm's risk preferences to be strongly reflected in its recent innovation strategy. That is, firms with an aggressive product innovation strategy should be the least risk-averse firms, while those following a conservative innovation strategy should be the most risk-averse. We include a control variable in the analysis for the firm's relative innovativeness in its industry. The firm's relative innovativeness (PASTINNO) is calculated using its average share of new product sales relative to its industry in the pre-sample period (the same period over which we calculate our uncertainty measure).

Public R\&D subsidy awards (GOV) are measured by a dummy variable indicating whether the firm received R\&D subsidies either from local government agencies, the German federal government, or the European Commission. In our sample, $32 \%$ of firms received $R \& D$ grants from public sources.

Market type, the degree of competition, and capital intensity may also influence the firm's investment decision. We control for market type using eleven industry dummies variables. To measure the degree of competition, we include each market's seller concentration using the Herfindahl index based on shares of market sales, $\ln (H H I) .{ }^{6}$ Capital intensity (KAPINT) is measured as physical assets (in million DM)

\footnotetext{
5 In the literature, researchers have used a variety of measures of uncertainty (see Carruth et al. 2000, and Bulan 2005). We believe our measure is attractive since we focus on R\&D investment. We should note, however, that we have limited pre-sample information on this variable (three to six data points per firm) and this limits our ability to explore alternative adjustments for trends.

6 As alternative measure for market power, we also used the market share on the 3-digit NACE industry level. NACE is the European standard industry classification. As the results never changed, we omit a detailed presentation of regressions using market share instead of the Hefindahl index.
} 
per employee to account for the fact that firms in more technology-intensive sectors may have a higher propensity to conduct $R \& D$ than those in more labor-intensive sectors.

With regard to other firm characteristics, we include controls for firm size, liquidity constraints, and governance structures. To account for heterogeneity in firm size, we use the number of employees at the firm. In our sample, $13 \%$ of observations are large firms with more than 500 employees. The median firm size in our sample is 113 employees. ${ }^{7}$ We include two controls for potential liquidity constraints. For access to external capital, we use the firm's credit rating, $\ln \left(\right.$ RATING), lagged one period. ${ }^{8}$ The credit rating is obtained from Creditreform which is the largest German rating agency. The rating is an index ranging from 100 to 600, where 600 is the worst and essentially corresponds to bankruptcy of the firm. For access to internal capital, we use a measure of the firm's average price-cost margin, $($ PASTPCM $)$, in the pre-sample period. ${ }^{9}$

$$
\begin{aligned}
& \operatorname{PASTPCM}_{i}=\frac{1}{T} \sum_{t=1}^{T} \text { PCM }_{i t} \\
& \text { with } P C M=(\text { Sales }- \text { staff cost }- \text { material cost }+ \text { R\&D }) / \text { Sales, }
\end{aligned}
$$

where the periods $t$ correspond to the pre-sample period as used for the uncertainty measure. For corporate governance, we include a dummy variable indicating whether the firm is associated with a group of companies (GROUP). These firms may have better access to capital through the parent company.

With German data, it is also important to control for the firm's location in Eastern Germany. Since the German re-unification in 1990, Eastern Germany has been transitioning from a planned economy to a market economy. As a result, the former large firms in the German Democratic Republic (the so-called "combinates") were either closed-down or have been privatized and split into several independent companies. The vast majority of these firms were founded after 1990. Since these firms may behave differently, we include a dummy variable EAST in the regressions.

One time dummy variable controls for other changing macroeconomic time effects. For instance, this would capture any changes in the risk-free interest rate. Table 1 below presents descriptive statistics of all variables used (for convenience the index $i$ indicating firm level variables is omitted).

\footnotetext{
7 We also used sales as an alternative control for firm size. This change does not affect our findings since the correlation between $\ln$ (employment) and $\ln$ (sales) is 0.93 .

8 For some firms, there was no rating available for the preceding year. In such cases we use ratings from one or two years earlier.

9 See Collins and Preston (1969), or Ravenscraft (1983). Scholars who have used such measures to test for financial constraints typically add back R\&D to PCM, as R\&D is an expense and reduces profits in the period. If the firm would have decided not to invested in R\&D, PCM would have been accordingly higher and is therefore corrected by current R\&D in most empirical studies (see e.g. Harhoff 1998).
} 
Table 1 Descriptive statistics (925 observations)

\begin{tabular}{|c|c|c|c|c|}
\hline Variable & Mean & Std. Dev. & Min & $\operatorname{Max}$ \\
\hline$R \& D_{t}$ (in million $\left.\mathrm{DM}\right)$ & 7.583 & 73.43 & 0 & 1797.4 \\
\hline $\begin{array}{l}R \& D_{t} / \text { Sales }_{t}(\text { Sales }=\text { total sales } \\
\text { in million } \mathrm{DM})\end{array}$ & 0.027 & 0.055 & 0 & 0.688 \\
\hline$U N C E R_{t}$ (uncertainty measure) & 1.000 & 1.438 & 0.001 & 8.676 \\
\hline $\begin{array}{l}G O V_{t}(\mathrm{R} \& \mathrm{D} \text { subsidy dummy } \\
\text { variable) }\end{array}$ & 0.316 & 0.465 & 0 & 1 \\
\hline $\begin{array}{l}\text { PASTINNO }_{t} \text { (average share of } \\
\text { new product sales in pre-sample } \\
\text { period relative to industry) }\end{array}$ & 1.424 & 1.039 & 0.006 & 6.822 \\
\hline $\begin{array}{l}\text { PASTPCM }_{t-1} \text { (price-cost margin } \\
\text { in pre-sample period) }\end{array}$ & 0.272 & 0.147 & -0.909 & 0.826 \\
\hline$E M P_{t}$ (number of employees) & 534.176 & 2728.72 & 5 & 43118 \\
\hline$E A S T_{t}$ (location dummy variable) & 0.368 & 0.482 & 0 & 1 \\
\hline $\begin{array}{l}K A P I N T_{t} \text { (Physical assets in mil- } \\
\text { lion DM/EMP) }\end{array}$ & 0.082 & 0.095 & 0.002 & 0.938 \\
\hline$H H I_{t-1}$ (industry concentration) & 47.796 & 67.956 & 3.441 & 427.702 \\
\hline$C R_{t-1}$ (credit rating index) & 216.896 & 74.004 & 100 & 600 \\
\hline$D 2000_{t}$ (year dummy variable) & 0.551 & 0.498 & 0 & 1 \\
\hline$G R O U P_{t}$ (group dummy) & 0.381 & 0.486 & 0 & 1 \\
\hline${ }^{*} S H A R E_{t-1}$ (market share) & 0.006 & 0.021 & 0.001 & 0.268 \\
\hline
\end{tabular}

Note: 11 industry dummy variables are not presented

* This variable was only considered for robustness tests. Detailed regression results are omitted as the results presented below did not change

\section{Empirical Results}

Table 2 presents our regression results. We consider two specifications for each of the dependent variables, $\ln (\mathrm{R} \& \mathrm{D})$ and $\ln (\mathrm{R} \& \mathrm{D} / \mathrm{Sales})$ : Models $\mathrm{A}$ and $\mathrm{C}$ present the baseline results without the interaction term between uncertainty and R\&D subsidies in order to test hypotheses 1 and 2. Models B and D include the interaction term to test our third hypothesis that public R\&D subsidies mitigate the disincentive for R\&D investment caused by uncertainty.

We began our analysis using homoscedastic Tobit models. However, since the presence of heteroscedasticity can lead to inconsistent coefficient estimates, we performed several tests. We applied Lagrange Multiplier tests on the basis of the homoscedastic models to select variables potentially causing heteroscedasticity, ${ }^{10}$ which were subsequently implemented into heteroscedastic regressions where we consider the variance $\sigma_{i}^{2}$ of observation $i$ being of the form $\sigma_{i}=\sigma \exp \left(\mathrm{z}_{i}^{\prime} a\right)$ with $z$ denoting the vector of variables in the heteroscedasticity term and $a$ the additional coefficients to be estimated. The LM-tests suggest that industry dummy variables and size dummy variables (based on employment) should be used in the variance function. It turned out that homoscedasticity is rejected in all specifications. Consequently we only present the heteroscedasticity-consistent estimates. Table 2 also reports the statistics of Likelihood ratio tests on heteroscedasticity.

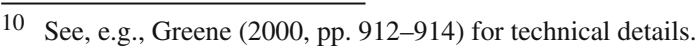


Table 2 Tobit regressions ${ }^{a}$

\begin{tabular}{|c|c|c|c|c|}
\hline \multirow[t]{3}{*}{ Variables } & \multicolumn{4}{|c|}{ Dependent variable } \\
\hline & A & B & $\mathrm{C}$ & $\mathrm{D}$ \\
\hline & $\ln (\mathrm{R} \& \mathrm{D})$ & $\ln (\mathrm{R} \& \mathrm{D})$ & $\ln (\mathrm{R} \& \mathrm{D} /$ Sales $)$ & $\ln (\mathrm{R} \& \mathrm{D} /$ Sales $)$ \\
\hline UNCER & $\begin{array}{c}-0.448^{* * *} \\
(0.099)\end{array}$ & $\begin{array}{c}-0.617^{\text {*** }} \\
(0.128)\end{array}$ & $\begin{array}{c}-0.508^{* * *} \\
(0.109)\end{array}$ & $\begin{array}{c}-0.742^{* * *} \\
(0.139)\end{array}$ \\
\hline$U_{N C E R^{*}} G O V$ & & $\begin{array}{l}0.407^{* *} \\
(0.182)\end{array}$ & & $\begin{array}{l}0.602^{* * * *} \\
(0.201)\end{array}$ \\
\hline$G O V$ & $\begin{array}{l}2.583^{* * *} \\
(0.244)\end{array}$ & $\begin{array}{l}2.257^{* * *} \\
(0.281)\end{array}$ & $\begin{array}{l}2.583^{* * *} \\
(0.272)\end{array}$ & $\begin{array}{l}2.100^{* * * *} \\
(0.309)\end{array}$ \\
\hline PASTINNO & $\begin{array}{l}1.183^{* * *} \\
(0.122)\end{array}$ & $\begin{array}{l}1.165^{* * *} \\
(0.123)\end{array}$ & $\begin{array}{l}1.268^{* * *} \\
(0.135)\end{array}$ & $\begin{array}{l}1.243^{* * *} \\
(0.134)\end{array}$ \\
\hline $\ln (E M P)$ & $\begin{array}{l}1.135^{* * *} \\
(0.090)\end{array}$ & $\begin{array}{l}1.154^{* * *} \\
(0.090)\end{array}$ & $\begin{array}{l}0.369^{* * *} \\
(0.095)\end{array}$ & $\begin{array}{l}0.389^{* * *} \\
(0.094)\end{array}$ \\
\hline$E A S T$ & $\begin{array}{c}-0.974^{* * *} \\
(0.257)\end{array}$ & $\begin{array}{c}-0.966^{* * *} \\
(0.258)\end{array}$ & $\begin{array}{c}-0.696^{* *} \\
(0.289)\end{array}$ & $\begin{array}{c}-0.684^{* *} \\
(0.288)\end{array}$ \\
\hline KAPINT & $\begin{array}{c}1.823 \\
(1.334)\end{array}$ & $\begin{array}{c}1.826 \\
(1.350)\end{array}$ & $\begin{array}{c}1.567 \\
(1.314)\end{array}$ & $\begin{array}{c}1.462 \\
(1.315)\end{array}$ \\
\hline $\ln (H H I)(\mathrm{t}-1)$ & $\begin{array}{r}-0.061 \\
(0.120)\end{array}$ & $\begin{array}{r}-0.069 \\
(0.120)\end{array}$ & $\begin{array}{r}-0.092 \\
(0.129)\end{array}$ & $\begin{array}{r}-0.113 \\
(0.128)\end{array}$ \\
\hline PASTPCM & $\begin{array}{l}1.927^{* *} \\
(0.760)\end{array}$ & $\begin{array}{l}2.098^{* * *} \\
(0.767)\end{array}$ & $\begin{array}{l}1.644^{* *} \\
(0.832)\end{array}$ & $\begin{array}{l}1.908^{* *} \\
(0.835)\end{array}$ \\
\hline $\ln (R A T I N G)(\mathrm{t}-1)$ & $\begin{array}{r}-0.039 \\
(0.446)\end{array}$ & $\begin{array}{c}0.008 \\
(0.446)\end{array}$ & $\begin{array}{c}0.104 \\
(0.488)\end{array}$ & $\begin{array}{c}0.171 \\
(0.485)\end{array}$ \\
\hline D2000 & $\begin{array}{c}-1.119^{* * *} \\
(0.203)\end{array}$ & $\begin{array}{c}-1.106^{\text {*** }} \\
(0.203)\end{array}$ & $\begin{array}{c}-1.301^{* * *} \\
(0.218)\end{array}$ & $\begin{array}{c}-1.296^{* * *} \\
(0.216)\end{array}$ \\
\hline GROUP & $\begin{array}{c}0.314 \\
(0.235)\end{array}$ & $\begin{array}{c}0.312 \\
(0.234)\end{array}$ & $\begin{array}{c}0.298 \\
(0.242)\end{array}$ & $\begin{array}{c}0.276 \\
(0.240)\end{array}$ \\
\hline Intercept & $\begin{array}{c}-14.044^{* * *} \\
(2.790)\end{array}$ & $\begin{array}{c}-14.266^{* * *} \\
(2.801)\end{array}$ & $\begin{array}{c}-14.804^{* * *} \\
(3.033)\end{array}$ & $\begin{array}{c}-15.026^{* * *} \\
(3.033)\end{array}$ \\
\hline $\begin{array}{l}\text { Test on joint significance } \\
\text { of } 10 \text { industry dummies } \\
\left(\chi^{2}(10)\right)\end{array}$ & $110.51^{* * *}$ & $111.35^{* * *}$ & $109.32^{* * *}$ & $110.58^{* * *}$ \\
\hline \# of observations & 925 & 925 & 925 & 925 \\
\hline Log-likelihood & -1670.79 & -1668.22 & -1728.49 & -1723.86 \\
\hline McFadden $R^{2}$ & 0.185 & 0.186 & 0.157 & 0.159 \\
\hline $\begin{array}{l}\text { LR-test on heteroscedasti- } \\
\text { city }\left(\chi^{2}(15)\right)\end{array}$ & $33.05^{* * *}$ & $34.63^{* * *}$ & $45.17^{* * *}$ & $51.48^{* * *}$ \\
\hline
\end{tabular}

Note: Standard errors in parentheses. ${ }^{* * *}\left(* *,{ }^{*}\right)$ indicate a significance level of $1 \%(5 \%, 10 \%)$

${ }^{a}$ Heteroscedasticity term includes 10 industry dummy variables and 5 size dummy variables (based on the number of employees)

In Models $\mathrm{A}$ and $\mathrm{C}$, product market uncertainty (UNCER) is negative and highly significant. This finding indicates that firms reduce current R\&D as uncertainty increases. As pointed out by an anonymous referee, in order to conclude that firms are exhibiting real options investment behavior, it is important to hold constant their risk preferences since risk-averse firms may be reacting optimally to lower expected returns. The variable PASTINNO is included to control for this possibility. The regression results show that more aggressive innovators - firms that prefer a high risk strategy - 
invest more in R\&D while firms that pursue a low-risk strategy invest less in R\&D. With this control, we believe our findings support real options investment behavior.

The government R\&D subsidy dummy, which is positive and highly significant in Models A and C, suggests that receipt of a government subsidy increases firm R\&D investment. The marginal increase in $\mathrm{R} \& \mathrm{D}$ from receiving a subsidy is $39 \%$. This finding is in line with results found earlier for German data by Almus and Czarnitzki (2003) and Hussinger (2007). It confirms that subsidies yield higher R\&D spending at the firm level and that full crowding-out effects are not present, on average. Also, it is clear that the impact of public R\&D subsidies on firm R\&D investment is not due to relaxing the firm's financial constraints. The models include controls for access to internal and external capital. Of these variables, our variable for access to internal capital, PASTPCM, is positive and significant while the external capital variable, $\ln (R A T I N G)$, in not significant. The financial constraint variables suggest that firms rely on internally generated funds to finance $R \& D$ investment.

In Models B and D of Table 2, the effect of uncertainty is allowed to depend on whether or not the firm received a government R\&D subsidy. Consistent with hypothesis 3, the results show that the interaction between product market uncertainty and the receipt of a government subsidy is positive and significant. This indicates that R\&D subsidies mitigate the disincentive for R\&D investment caused by uncertainty. Considering the magnitude of the effect, we cannot reject the hypothesis that R\&D subsidies completely offset the reduction in R\&D due to product market uncertainty: Wald-tests for equal magnitudes of the coefficients on UNCER and (-UNCER* GOV) yield a chi-squared statistic of 2.11 for model B and 0.75 for D, which are both insignificant at the $10 \%$ level. For those firms with no subsidy, product market uncertainty continues to be associated with lower firm R\&D investment.

Several of the other covariates are significant and have the expected signs. Firm size is positive and significant, indicating that larger firms invest more in R\&D. Firms located in Eastern Germany invest less in R\&D than do Western German firms, all else constant. As shown by the time dummy variable, R\&D investment levels did, on average, decrease between 1998 and 2000 conditional on the other covariates. There are large differences in R\&D investment among industries, which is shown by the test of joint significance of the industry dummy variables. Highest investment (conditional on the other covariates) is achieved in industries designated as 'medical, optical and precision instruments', 'automotives', 'chemicals including pharmaceuticals' and 'machinery and equipment'.

The government subsidy dummy variable may be endogenous, due to the government selection process for choosing which firms to subsidize. Depending on the selection criteria, this endogeneity bias may be upward or downward. For our analysis, we would like to be confident that endogeneity bias is not driving our results. To do this, we account for the government selection process using a parametric treatment model. This is a two stage estimation procedure similar in spirit to the standard Heckman approach (see Greene 2000, pp. 933-934, for technical details). Given the available data, we identified potential instruments as those variables that are insignificant as determinants of the firm's R\&D. The second stage results show that selectivity into the 
government subsidy program is not significant, ${ }^{11}$ and our results presented in Table 2 continue to hold.

\section{Conclusions}

Drawing on the insights from the real options approach to investment under uncertainty, this paper shows that public R\&D subsidies mitigate the disincentive to invest in R\&D stemming from uncertainty. Although public R\&D subsidies do not act directly to reduce demand uncertainties, they can offset the incentive effect of these uncertainties by increasing the expected return to the firm's R\&D investment. Controlling for financial constraints and a variety of other factors, our results hold even though some of the knowledge generated from a firm's own R\&D investment spills over to other firms and economic actors.

Moreover, there are two notable implications of our analysis: First, public policies intended to increase private $R \& D$ investment can achieve this objective by reducing the degree of uncertainty in the product market. While not tested empirically, Kremer and Glennerster (2000), Kremer (2001a,b), and others have used this insight to argue that purchase precommitments and R\&D prizes may be a valuable mechanism for stimulating R\&D investment and innovation in areas ignored by private firms, such as Malaria vaccines. Second, our results suggest that private firms may be using public R\&D subsidy programs to fund their most uncertain projects. It is widely known that program administrators have a difficult problem picking proposals that have high social returns but insufficient private returns. While probably unintended, these administrators may still be stimulating private $R \& D$ by reducing the effect of uncertainty on private project returns.

While this research provides the first systematic evidence that public R\&D subsidies mitigate the effect of product market uncertainty on private $R \& D$ investment, there are a number of caveats. First, our measure of uncertainty is based on prior firm experience. If firms form their expectations of future market uncertainty through other mechanisms, then our measure is weakened. Second, we cannot control for firm fixed effects with our cross-sectional data. Fixed effects might provide a better control for a firm's investment or risk preferences than our innovation strategy proxy. Third, product market uncertainty is only one form of uncertainty that may influence R\&D and other capital investments by the firm. As new and richer data become available, researchers may be able to isolate the sources of uncertainty more specifically and thereby deepen our understanding of the relationship between uncertainty and investment.

Acknowledgements We are grateful to the MIP team at ZEW Mannheim for providing the survey data, and to an anonymous referee as well as the editor for helpful comments

\section{References}

Abel, A. B. (1983). Optimal investment under uncertainty. American Economic Review, 73, 228-233.

11 These regressions are available from the authors upon request. 
Aerts, K., Czarnitzki, D., \& Fier, A. (2006). Econometric evaluation of public R\&D policies: Current state of the art. Unpublished manuscript, KU Leuven.

Almus, M., \& Czarnitzki, D. (2003). The Effects of Public R\&D Subsidies on Firms' Innovation Activities: The Case of Eastern Germany. Journal of Business and Economic Statistics, 21(2), 226-236.

Arrow, K. J. (1962). Economic welfare and the allocations of resources of invention. In R. R. Nelson (Ed.), The rate and direction of inventive activity: Economic and social factors (pp. 609-625). Princeton: Princeton University Press.

Bertola, G. (1988). Adjustment costs and dynamic factor demands: Investment and employment under uncertainty. Ph.D. Thesis, MIT, Cambridge.

Bulan, L. T. (2005). Real options, irreversible investment and firm uncertainty: New Evidence from U.S. firms. Review of Financial Economics, 14, 255-279.

Carruth, A., Dickerson, A., \& Henley, A. (2000). What do we know about investment under uncertainty? Journal of Economic Surveys, 14(2), 119-153.

Collins, N. R., \& Preston, L. E. (1969). Price-cost margins and industry structure. Review of Economics and Statistics, 51(3), 271-286.

Czarnitzki, D. (2006). Research and development in small and medium-sized German enterprises: The role of financial constraints and public funding. Scottish Journal of Political Economy, 53(3), 335-357.

Czarnitzki, D., \& Licht, G. (2006). Additionality of public R\&D grants in a transition economy: The case of Eastern Germany. Economics of Transition, 14(1), 101-131.

David, P. A., Hall, B. H., \& Toole, A. A. (2000). Is public R\&D a complement or substitute for private R\&D? A review of the econometric evidence. Research Policy, 29(4-5), 497-529.

Dixit, A. K. (1992). Investment and hysteresis. Journal of Economic Perspectives, 6(1), 107-132.

Dixit, A. K., \& Pindyck, R. S. (1994). Investment under uncertainty. Princeton, NJ: Princeton University Press.

Duguet, E. (2004). Are R\&D subsidies a substitute or a complement to privately funded R\&D? Evidence from France using propensity score methods for non experimental data. Revue d'Economie Politique, 114(2), 263-292.

Goel, R. K., \& Ram, R. (2001). Irreversibility of R\&D investment and the adverse effect of uncertainty: Evidence from the OECD countries. Economic Letters, 71, 287-291.

Görg, H., \& Strobl, E. (2007). The effect of R\&D subsidies on private R\&D. Economica, 74(2), 215-234.

González, X., Jaumandreu, J., \& Pazó, C. (2005). Barriers to innovation and subsidy effectiveness. RAND Journal of Economics, 36, 930-950.

Greene, W. H. (2000). Econometric analysis (4th ed.). Upper Saddle River: Prentice-Hall.

Gusio, L., \& Parigi, G. (1999). Investment and demand uncertainty. Quarterly Journal of Economics, 114(1), $188-227$.

Hall, B. H. (2002). The financing of research and development. Oxford Review of Economic Policy, 18(1), 35-51.

Harhoff, D. (1998). Are there financing constraints for innovation and investment in German manufacturing firms? Annales d'Économie et de Statistique, 49/50, 421-456.

Hartman, R. (1972). The effects of price and cost uncertainty on investment. Journal of Economic Theory, $5,258-266$.

Hussinger, K. (2007). R\&D and subsidies at the firm level: An application of parametric and semi-parametric two-step selection models. Journal of Applied Econometrics, forthcoming.

Hyytinen, A., \& Toivanen, O. (2005). Do financial constraints hold back innovation and growth? Evidence on the role of public policy. Research Policy, 34, 1385-1403.

Klette, T. J., Møen, J., \& Griliches, Z. (2000). Do subsidies to commercial R\&D reduce market failures? Microeconometric evaluation studies. Research Policy, 29(4-5), 471-495.

Kremer, M. (2001a). Creating markets for new vaccines: Part I: Rationale. In A. B. Jaffe, J. Lerner, \& S. Stern (Eds.), Innovation policy and the economy (Vol. 1). Cambridge: MIT Press.

Kremer, M. (2001b). Creating markets for new vaccines: Part II: Design issues. In A. B. Jaffe, J. Lerner, \& S. Stern (Eds.), Innovation policy and the economy (Vol. 1). Cambridge: MIT Press.

Kremer, M., \& Glennerster, R. (2000). A better way to spur medical research and development. Regulation, 23(2), 34-39.

Lach, S. (2002). Do R\&D subsidies stimulate or displace private R\&D? Evidence from Israel. Journal of Industrial Economics, 50(4), 369-390.

Leahy, J. V., \& Whited, T. M. (1996). The effect of uncertainty on investment: Some stylized facts. Journal of Money, Credit and Banking, 28(1), 64-83. 
McDonald, R., \& Siegel, D. (1986). The value of waiting to invest. Quarterly Journal of Economics, 101, 707-727.

Nelson, R. R. (1959). The simple economics of basic scientific research. Journal of Political Economy, 67, 297-306.

Pindyck, R. S. (1988). Irreversible investment, capacity choice and the value of the firm. American Economic Review, 78(5), 969-985.

Pindyck, R. S. (1991). Irreversibility and the explanation of investment behaviour. In D. Lund \& B. Oksendal (Eds.), Stochastic models and option values. Amsterdam: North Holland.

Ravenscraft, D. J. (1983). Structure-profit relationships at the line of business and industry level. Review of Economics and Statistics, 65, 22-31.

Toole, A. A. (2007). Does public scientific research complement private research and development investment in the pharmaceutical industry. The Journal of Law and Economics, 50(1), 81-104.

Von Kalckreuth, U. (2000). Exploring the role of uncertainty for corporate investment decisions in Germany. Discussion Paper 5/00, Economic Research Group, Deutsche Bundesbank, Frankfurt. 